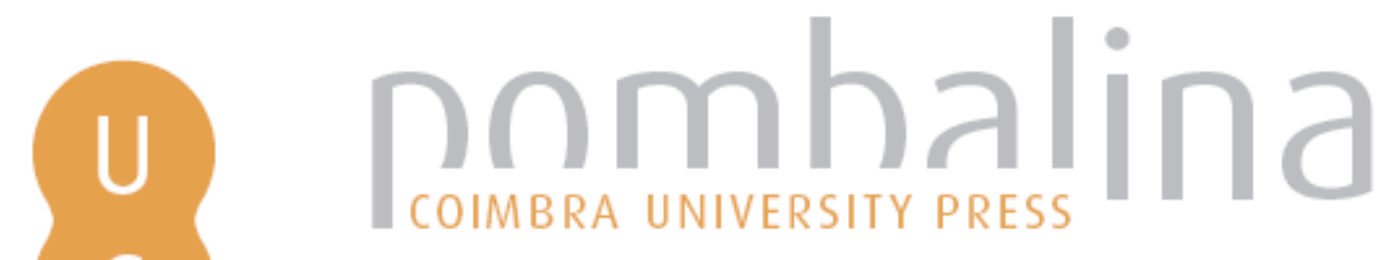

\title{
Music and lyrics: notes on Italian songwriting
}
Autor(es):
Babino, Cristina
Publicado por: Imprensa da Universidade de Coimbra
URL
persistente:
URI:http://hdl.handle.net/10316.2/40001
DOI:
DOI:https://doi.org/10.14195/978-989-26-1115-0_9

Accessed : $\quad$ 26-Apr-2023 16:21:09

A navegação consulta e descarregamento dos títulos inseridos nas Bibliotecas Digitais UC Digitalis, UC Pombalina e UC Impactum, pressupõem a aceitação plena e sem reservas dos Termos e Condições de Uso destas Bibliotecas Digitais, disponíveis em https://digitalis.uc.pt/pt-pt/termos.

Conforme exposto nos referidos Termos e Condições de Uso, o descarregamento de títulos de acesso restrito requer uma licença válida de autorização devendo o utilizador aceder ao(s) documento(s) a partir de um endereço de IP da instituição detentora da supramencionada licença.

Ao utilizador é apenas permitido o descarregamento para uso pessoal, pelo que o emprego do(s) título(s) descarregado(s) para outro fim, designadamente comercial, carece de autorização do respetivo autor ou editor da obra.

Na medida em que todas as obras da UC Digitalis se encontram protegidas pelo Código do Direito de Autor e Direitos Conexos e demais legislação aplicável, toda a cópia, parcial ou total, deste documento, nos casos em que é legalmente admitida, deverá conter ou fazer-se acompanhar por este aviso.

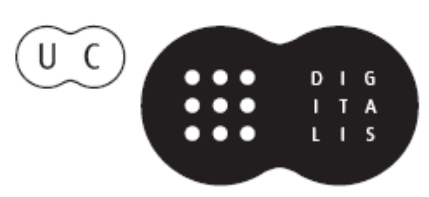




\section{JOÃO CORRÊA-CARDOSO MARIA DO CÉU FIALHO}

(Coordenadores)

\section{A LINGUAGEM NA PÓLIS}

IMPRENSA DA UNIVERSIDADE DE COIMBRA COIMBRA UNIVERSITY PRESS
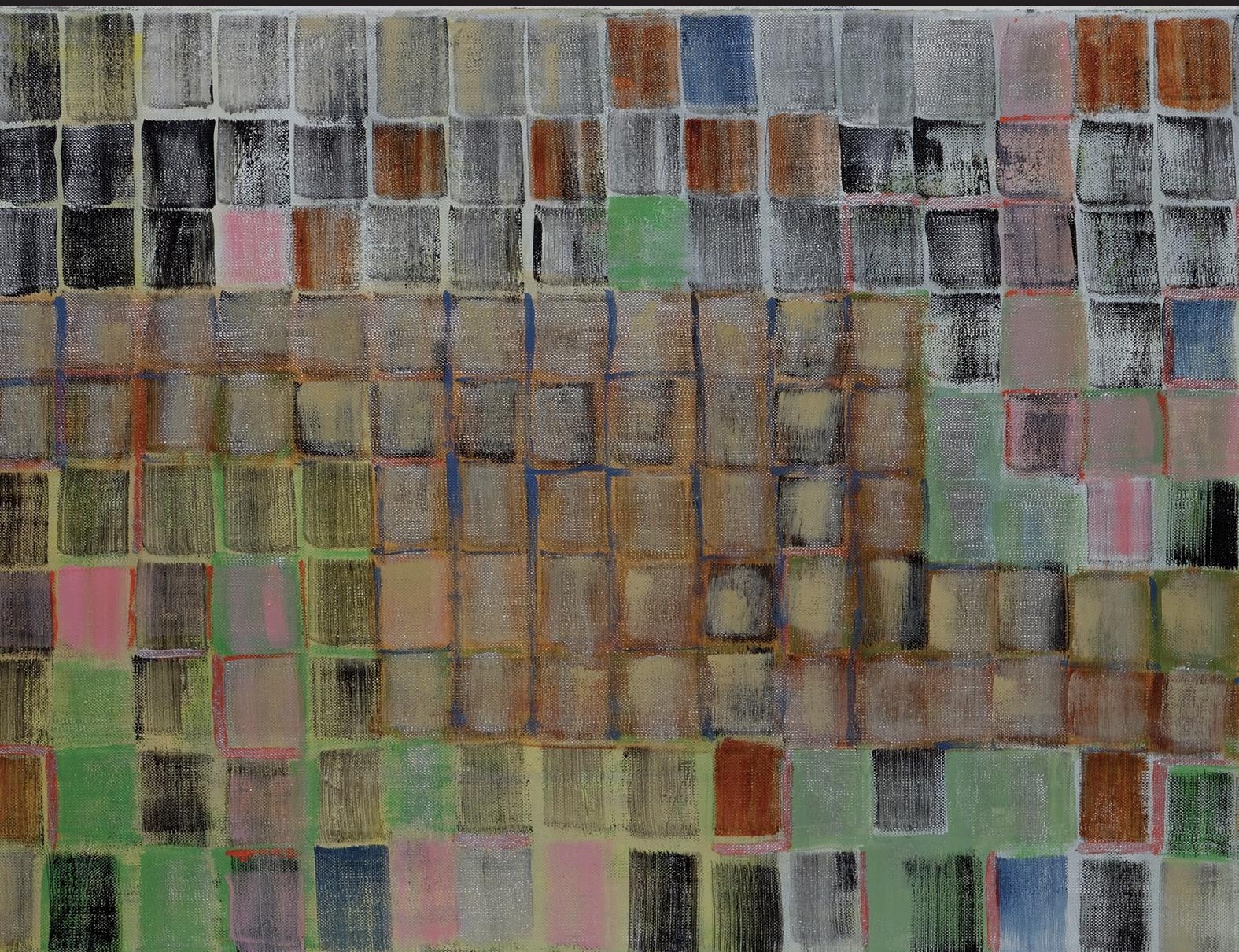


\title{
MUSICAND LYRICS.
}

\section{NOTES ON ITALIAN SONGWRITING}

\author{
Cristina Babino \\ Poeta em Residência \\ Universidade de Coimbra 2008 \\ cristinababino@gmail.com
}

Resumo: Longa viagem pela história literária e cultural da canzone italiana tomada como uma das possíveis marcas definitórias da expressão do espírito itálico.

Palavras chave: canzone; literatura; música; história da cultura italiana; semiótica.

\begin{abstract}
Canzone as a musical/literary form and as a cultural phenomenon reflects the search for a national identity and the peculiarity of Italy, a Country always defined by contrasts and differences, by both geographical and symbolic borders.
\end{abstract}

Keywords: canzone; literature; music; history of Italian culture; semiotics.

\section{Preliminary notes on Canzone}

The first example of canzone as a literary composition accompanied by music is the choral poetry of Greek poet Pindarus (Vth C BC). 
It is in the Middle Ages, then, that these compositions spread consistently, particularly in France, where troubadours travelled from court to court singing their chansons while playing an instrument.

Canzone as a genre changed through the centuries and poetry slowly developed losing its original musical accompaniment. In Italy, it was largely used by Sicilian and Stilnovo poets in the XIIIth C., then refined by Francesco Petrarca and later mastered by Giacomo Leopardi; this noble metrical composition became, in time, something different from the popular canzone (song), which continued to flourish in common oral and musical culture and in such a peculiar genre as Italian Melodramma.

The great literary tradition of Italian poetry has many points of contact with music, and canzone in particular: just to quote a few eminent examples, Dante writes the Divina Commedia and divides it into Cantiche, Petrarca writes Canzoni and he collects them into the Canzoniere (the same title of Umberto Saba's famous collection of poems, centuries after), Orlando furioso and La Gerusalemme liberata are full-length epic poems in rhyme also called Cantari, while Giacomo Leopardi's major poetry book is called "Canti". ${ }^{1}$

Canzone (song) as a musical/literary form and as a cultural phenomenon reflects the search for a national identity and the peculiarity of Italy, a Country always defined by contrasts and differences, by both geographical and symbolic borders. The construction of Italian national identity was longly influenced by its historical, political, cultural and consequently linguistic fragmentation, and by the huge role played by the ecclesiastical power.

Italy as a nation was born in fact only in 1861 - and a complete law on proper compulsory education was introduced only in 1923

${ }^{1}$ Alfio Squillaci in La canzone italiana tra poesia e quotidianità. Appunti sparsi per una lezione da tenersi all'Istituto della Comunicazione di Milano, maggio 2003, http://www.lafrusta.net/fili_canzone_italiana.html 
by the Fascist regime - but it can well be said that only with the advent of television, in the Fifties, Italian as a language fully spread throughout the nation, reaching people in their own homes, where they kept using their local dialects, often languages on their own.

We can identify two waves in the popular tradition of Italian musical storytelling: one widespread in the North, characterized by the narration of events and tales and constructed as a monologue of the singer, the other one widespread in the South, mainly corresponding to the form of dialogue, often a love dialogue, or fight (strambotto or stornello).

Canzone napoletana (Neapolitan song: villanella, serenata) is particularly interesting as it is the only form of expression in dialect that was at the same time "national" and popular, due to the fact that Naples was already back in the XVIth C. a reign on its own.

Neapolitan song can be considered as an actual link between popular culture - as it originated from the lower classes - and the Illuminist bourgeois class. It was then in the XIXth C. that Romanticism, with its interest in recovering legacy and traditions of the past, boosted the attention on folk and popular songs and oral tales: once written down and passed on, this oral and "underground" heritage became part of the shared literary culture of a newborn nation.

Alongside with Canzone, the poetic tradition offers other compositions meant to be accompanied by music: Madrigale, Frottola, Romanza (which will be recovered mostly in Opera singing), and Ballata (ballad). The latter is a poetic composition, born in French Provence around XII C., written to be sung and danced, made of stanzas and refrains, whose structure remains almost unchanged through the centuries, reaching modern song (one example of modern ballad: Fabrizio De André's La canzone di Marinella). Modern ballad is characterized by an easy and clear melody, where the narrative element (a tale) prevails on a lyrical attitude. 


\section{From Melodramma to Canzone all'italiana}

Italian popular song is a peculiar, expression of the national collective genius ${ }^{2}$ : it does not originate from a Romantic kind of solitary talent, but from a number of often unknown composers. Before the age of songwriters, the Italian popular song is perceived as a common legacy, left by an anonymous mass of writers, arrangers, musicians, performers: it was a privileged form of popular expression.

The combination of elements from the popular song (simple and direct expression, fixed themes and stereotypes) and from Melodramma (dramatic interpretation and emphatic singing) is at the origin, at the end of XIXth C., of the so-called Canzone all'italiana, the well-known melodic cliché of Italian song, doomed to be successful until the Sixties.

Canzone all'italiana joins characters of Romanza da salotto and Operetta melodies: it develops through the XXth C., reaching its highest popularity (also thanks to means of reproduction such as the record player and the vinyl) between 1950 and 1980, and in particular between the first Sanremo Festival of Italian Song (1951) and the birth of the first free radios (1974).

Song as we intend it today is a sound-tale 3 : not only a tale told in words, but a form that joins a melody, simple or complex, together with words. Lyrics and music create a unicum, and are so intertwined that one cannot be divided from the other without losing something of their meaning.

\footnotetext{
2 Ibidem.

${ }^{3}$ Definition borrowed from songwriter and professor Roberto Vecchioni, in Lezioni sulla canzone d'autore italiana, originally published on http://www.vecchioni.it (resource no longer available online), lessons which served as main reference for these notes on Canzone all'italiana.
} 
The first example of this sound-tale can be traced down in the XIXth C. and identified with the Melodramma: a composition both popular and erudite, which combines sensualism and puritanism, sacred and mundane.

Melodramma was a genuinely peculiar Italian phenomenon: it reached the masses making something thought to entertain the élites enjoyable to audiences of different social status. Everybody could identify at some level with the contents of Melodramma, and the lowest social classes actually start learning Italian by going to the theatre. Opera celebrated all social classes: it actually helped in unifying the national collective spirit of a newborn nation. The enormous success of Melodramma led to the diffusion of theatres and café-concerto all around Italy: tenors, baritones, orchestras performed in front of an audience mostly made by bourgeois, who saw their social class here represented at best.

It might be useful to take a few steps backwards and underline that in Italy Controriforma (Counter Reformation, 1560-1648) and the long lasting prohibition of the ecclesiastical authorities to translate the Sacred Writings from Latin to common language played an important role in the cultural development of the masses.

If in Northern Europe, thanks to Luther's Protestant Reformation, civilization progressed mostly through the spreading of reading and writing at different levels of society (often learnt on the Bible itself), in Italy instead the above mentioned prohibition blocked the learning of writing as a mass phenomenon 4 : the use of written language was a privilege reserved to politicians, clergy and higher classes only, while the masses continued for a very long time to express themselves through the more natural and direct oral way (using almost exclusively their own regional dialects).

\footnotetext{
${ }^{4}$ Alfifo Squillaci points this out in La canzone italiana tra poesia e quotidianità, cit.
} 
While elsewhere in Europe the written word was boosted by the great diffusion of novels, in Italy a lyric-melodic inclination prevailed, expressed at its best by Opera singing. Musical communication is in fact the privileged way of expression of a society mostly made of semi-illiterates, and that is why Melodramma developed as a gloriously and uniquely Italian phenomenon.

The element of Melodramma which is closest to modern song is the Aria: a composition accomplished in itself, which can be performed separately from the rest of the opera. It is usually sung by one singer, who in this passage opens his heart to the audience, expressing his/her inner feelings and creating an emotional suspension in the plot. The Aria (such as Nessun dorma or La donna è mobile) was therefore soon extrapolated from its original musical context and sung on its own by singers and interpreters 5 .

During XIX C., Aria turned into Romanza: somehow a concentrate of Opera, it can already be considered as a song, the prototype of the Canzone all'italiana and follows fixed clichés, like a moving plot, easily identified and opposable characters (good/evil, poor/ rich), love as the main subject (mostly a unhappy and tormented love).

Canzone all'italiana remained something out of time, isolated and unmodified, a way of expression and entertainment that is far from the individual searches for uncertain truths that arose in the XXth C. This persistence of stereotypes and anachronisms was nevertheless very useful to the Fascist regime to boost its ideal of home-family-homeland and to keep consciences asleep through easy entertainment. This delay in the development of song as a form of art will last almost until the Sixties, also due to the widespread and strong moralist influence of the Church.

5 For further details about the musical development from Aria to Canzone all'italiana see Roberto Vecchioni in Lezioni sulla canzone d'autore italiana, cit. 
Canzone all'italiana, as we said, originated from the evolution of Romanza, slowly transformed in a more direct, accessible and brief way of expression through singing, often making of the Melodramma epic a moral anecdote easier to be sung in small theatres (riviste) and café chantant, and easier to be appreciated by a larger audience, greatly impressed by rhetoric, erotic languor and common literary stereotypes.

\section{Sanremo Italian Song Festival and the birth of Canzone d'autore}

For a long time, Italian music industry has been synonym with Sanremo Italian Song Festival, the longest lasting music contest in Italian history.

Sanremo is the national festival of commercial popular song, a "consumer product" more and more spread in a fast growing Country, joyfully out of WWII, whose optimism is boosted by new technologies and industrial innovations.

Since 1951, Sanremo is the display window of popular song, whose topic is mostly love: chaste, idyllic or unhappy, always without any references to sex and real life, in form of easy, standard and repetitive rhythms and melodies.

Despite the often low artistic value of Sanremo songs, the festival is for a long time the only way for new authors to be introduced to the national music industry and to a wider public.

Therefore, many valuable singers and songwriters moved their first steps on Sanremo stage, often having no success at all when they first appeared.

Moreover, during the Sixties, TV - controlled and censored by the State - gained importance as new media of mass communication, 
much more powerful, direct and intrusive than radio: broadcasting the Festival, TV immediately made it a nationwide event.

Italian song started a process of modernisation only in the late Fifties, during post-war reconstruction: a time characterized by the rising of progressive movements in politics and culture (Socialists were finally part of the Government, even in a strong ChristianDemocrat leadership, and worker Unions gained more and more relevance), a wider compulsory education among all social classes, the birth of new vanguard literary movements debating about the role of intellectuals and their engagement in social and political issues, the diffusion of cinema and television which made communication and circulation of ideas quicker and more effective, the Italian economic "miracle" and the consequent urbanisation, with urban centres becoming more and more relevant ${ }^{6}$.

A remarkable factor of change was also the arrival in Europe, between the Fifties and the Sixties, of such musical phenomena as rock, jazz and beat. While jazz influences élite portions of the musical world, rock (and later beat) becomes a mass phenomenon, in connection with the new society of consumers of the Western world.

As for rock, most part of its success is due to the fact of being adopted by young generations, the new consumers of the western society. Rock determines a renewal of rhythms and styles. In Italy, anyway, the rock wave is very soon tamed by the national record industry, changed and sweetened in order to reflect the needs of the Italian young generations and their social and economical contest.

The first and greatest breakthrough into the old, traditional melodic song model proposed by Sanremo Festival came with Domenico Modugno, who in 1958 started a new era for Italian song with Nel Blu dipinto di blu (Volare): interpretation began to be considered

6 Ibidem. 
one with the lyrics, starting to express deeper feelings and a new artistic sensitivity.

Later, the suicide of songwriter Luigi Tenco during the 1967 Sanremo music contest made new authors aware of the merely commercial laws behind the Festival and of their moral necessity of being against the political and social establishment. The real change in Italian musical panorama came with the followers of the so-called Beat generation, characterised by a strong rebellion towards the established political power (the conservative Christian Democrats at the time), which will culminate with 1968 riots.

The wave of political and social engagement of the Sixties spread in Italy, along with the phenomenon of songwriters and the songs of protest, with a conscious recovery of the oral tradition, in particular the folk songs, as a naif but true and sincere way of expression, typical of workers and lower social classes, opposed to the cloudy and tricky language of politics and established power.

Most part of the revisited popular songs recovered from anarchical songs of early XXth C., i.e. socialist and communist chants, especially about the Resistance to Nazifascism: it is no surprise that these songs were rediscovered in a time of students' fights and struggles of workers (significant songwriters of this movement were: Ivan Della Mea, Alberto D'Amico, Paolo Pietrangeli and Gualtiero Bertelli, who often sang in Venetian dialect, Alfredo Bandelli, who sang about workers, emigrated abroad and worked in a factory himself) ${ }^{7}$.

La ballata per Pinelli is a particular interesting song of social and political protest: the text was improvised by a group of activists in 1969, the day after the funerals of Giuseppe Pinelli, an anarchist mysteriously fallen out of a window of the police headquarters in

7 Ibidem. 
Milan during an interrogation about the terrorist bomb attack of Piazza Fontana, when many people were killed ${ }^{8}$.

Starting from the late Fifties, eminent writers and intellectuals (like Franco Fortini and Italo Calvino), tried to give popular and folk songs a proper cultural value and literary dignity, as they considered this popular heritage the only one genuinely national, completely Italian. Groups like Cantacronache and Nuovo Canzoniere Italiano showed something new: never before intellectuals and critics, who strongly supported their activity, had took an interest in folk songs.

Their aim was to make the gap between people and high culture smaller, promoting popular songs and culture. This attempt was however doomed to fail: new generations identified themselves much more in the individual search and rebellion that inspired songwriters than in old workers' hymns or Resistance's songs'.

In the meanwhile, Canzone allitaliana stood mostly anchored to its traditional patterns, favoured and promoted by the established Christian-Democrat political power, which had all interests in keeping the masses quiet with the repetition of old, reassuring romantic clichés. Canzone all'italiana lived on, although strongly opposed by critics and songwriters. But as we mentioned, in 1958 Domenico Modugno set a whole new standard by singing Nel blu dipinto di blu (Volare), the first songwriter's song to introduce a completely new idea of song as a piece of art, with new lyrics, language, contents and with a new idea of interpretation as a distinctive sign for the author/singer.

From this moment on, Canzone all'italiana will still survive, often only apparently modernized and evolved, but will gradually lose its relevance: in some cases, it sticks to its roots and schemes,

\footnotetext{
8 The same event will be revisited by Dario Fo in his famous theatrical pièce Morte accidentale di un anarchico.

9 Ibidem.
} 
in other it gets influenced by foreign artists, adapting to the Italian taste and mood.

But new authors, all very well educated, were deeply influenced by the new atmosphere around them and they projected these inputs in a new creative dimension. Emerging authors finally renewed the language traditionally used in lyrics, making it closer to people, more direct, and getting rid of old sentimentalism.

That is how Canzone d'autore (songwriter's song) was born, as an act of conscious breakthrough meant to inspire the new post-war generations ${ }^{10}$.

It soon became a "literary" genre on its own, an original product of foreign influences (like French chansonniers Brel and Brassens or Dylan) and popular heritage, re-elaborated through the individual poetic and creative strength of each author. Their inspiration came from the denial of social and political settings, of the hypocrisy leading the society they were born in, enriched after the war but somehow made asleep by the economic and political establishment.

Songwriters sang about a certain mal de vivre, with no certainties, the tension for freedom and social equality, the disrespect for established power, the mixture of feelings in their heart, where love is no more romantic and idealized, but it causes pain and leads to a continuous meditation. The language used was more contemporary, and the gap between lyrics and prose became smaller.

Important references to new songwriters were French chansonniers Brel and Brassens, but also XXth C. Italian poets (Eugenio Montale, Camillo Sbarbaro, Giorgio Caproni) Bob Dylan's ballads and some masters of American literature (Ernest Hemingway, Herman Melville, F. Scott Fitzgerald).

10 Ibidem. 
The phenomenon of songwriters, still characterised by an underground profile in the Sixties, exploded from the Seventies on, thanks to new media (TV, free radios, juke-boxes) gaining a prominent national importance both literarily and culturally.

\section{Caratteri della canzone d'autore}

Canzone d'autore (songwriter's song) «originates from two existing semantic models (poetic language and musical notation), but it is not simply the addition of the two". 11

It is an inseparable unity of a literary tale and a metric texture that accompanies words: music and lyrics cannot be divided, and they gain a new meaning with the unique interpretation given by the author-singer, whose charisma becomes part of the song itself.

Songwriter's song inherits from the poetic technique the use of figures of speech (metaphors, analogies, etc.) but making them more accessible to people, so that the logical link between image and sense is made more evident and immediate. ${ }^{12}$

Songwriter's song is a real breakthrough: lyrics are no longer slave to the melody, the scheme stanza-refrain is no longer compulsory and also the use of accents and rhymes becomes more flexible and significant. This apparent "impoverishment" is instead essential for songs to develop a new structure, an identity on their own. ${ }^{13}$

Non-professional musicians and writers ride this new wave before professionals: their revolution comes from urban centres, which have

11 As Roberto Vecchioni pointed out, "This apparent "impoverishment" is instead essential for songs to develop a new structure, an identity of their own." See Roberto Vecchioni's definition of Canzone d'autore for Treccani Encyclopedia (1998), available online at http://www.vecchioni.org/editoria/voce-canzone-dautorescritta-per-lenciclopedia-treccani/

12 Ibidem.
13 Ibidem. 
a cultural and social advantage on small towns and countryside: Rome (where new authors performed at the famous Folk Studio), Milan (influenced by theatrical performances), Genoa (more an individualist approach), Bologna (more social-political oriented). They are all linked, anyway, to the description of small daily things, apparently meaningless, but deeply meaningful for all of us.

If Canzone all'italiana was an invitation to a reassuring evasion, Canzone d'autore is the hymn to the engagement and meditation on real life issues and troubles. Along with the influence of French chansonniers and their new depth in expressing human feelings and fears, songwriters start using irony and wit to approach new themes.

The term cantautore (songwriter) first appears in Italy in 1960, introduced by the press agents of the major record company Ricordi. The song acquires, thanks to these authors, a new poetic dignity, keeping its traditional poetry, and yet gaining the attention of critics. But almost no famous poet writes songs at this early stage (only exception is Roberto Roversi), and this is significant of a certain gap which persists between this two close forms of arts. Italian songwriters gained their seat beside poets mixing high quality lyrics and music, making poetry itself much more accessible to the masses as a result. Thanks to its aesthetic and cultural relevance, songwriting soon succeeds in conquering its place in the national record industry.

The word songwriter brings a new element of distinction and artistic identity: it denotes the author of lyrics for music, who also performs alone, or supported by a band. With the progressive consolidation of this figure, it is also possible to study of the corpus of works, the poetic vision and recurrent themes of the songwriter, as one would do for a poet.

A songwriter is an author of music and lyrics, of songs that he sings and performs on his own in concerts, tours and public squares. His position is substantially outside music commercial and mass production, ruled by record multinationals. 
Due to his position, and to a more direct contact with people, the songwriter expresses his ideals and feelings in a way that is far, and often strongly against, the rules of power and the common sense, reflecting an outstanding poetic conception of the worldly things.

There are three major factors in a songwriter's song: interpretation, music and lyrics. The interpretation (or performance) is given by the voice, the execution, the scenic presence and charisma of the songwriter. As far as the melody is concerned, it is mostly linked to codified outlines, recovering and reassembling musical patterns already stored in the collective memory of the audience. Lyrics gain a new and deeper dignity and becomes the most relevant element in the song (which is usually constructed from the application of a text to the melody, and rarely vice versa). ${ }^{14}$

In a songwriter's song, the predominant factor is the text: the modern song preserves some characters of the classic literary song (like Petrarca's): the division in stanzas, the rhyme and some features as assonance. The refrain seems to go back, instead, to the ancient popular music, diffused in Italy and Europe since the XIIIth century. In time, words have become more and more relevant, and lyrics, originally quiet simple, become more and more similar to proper poetry. Thus, maintaining a strong link with the accompanying music and its execution.

Songwriters are, from a literary point of view, the most interesting musical phenomenon in Europe, spreading in different Countries, with different musical characteristics, but all with the same ideals and coordinates at the core.

The phenomenon of songwriters actually starts in France: new chansonniers compose songs that are mostly lyrical, dedicated to tales of unhappy lovers, often living in a poor Parisian banlieu.

14 Ibidem. 
Poets and writers like Prévert and Vian write songs for great interpreters, like Edith Piaf, who sings in the café-concert of the rive gauche. Around the extraordinary talent of Piaf, a group of new songwriters arises (Jacques Brel, Leo Ferré, Brassens, Yves Montand, Moustaki): this is how la chanson réaliste was born, doomed to influence the European cultural panorama, and beyond.

Songwriting develops remarkably in Italy too, mostly influenced by the production of French authors (Brel, Brassens, etc.) and North American songwriters (Dylan, Baez), and through the years an extraordinary number of talented artists appear on stage after the authentic breakthrough of Domenico Modugno: Luigi Tenco, Sergio Endrigo, Piero Ciampi, Then Fabrizio De André Gino Paoli, Bruno Lauzi, Ivano Fossati (the so-called Scuola Genovese), while in Milan songwriting develops a peculiar connection to theatrical performance, giving birth to the phenomenon of teatro-canzone (Giorgio Gaber, Enzo Iannacci), Francesco Guccini, the duo Lucio Battisti-Mogol, Lucio Dalla, Francesco De Gregori, Antonello Venditti, Rino Gaetano, Claudio Baglioni, Renato Zero, Angelo Branduardi, Riccardo Cocciante, Franco Battiato, Paolo Conte, Roberto Vecchioni, Pierangelo Bertoli, Vasco Rossi, only to name the most relevant Italian songwriters of all times. Among women songwriters, we must remember at least Teresa De Sio, Fiorella Mannoia, Gianna Nannini, Loredana Bertè, Mia Martini and younger Carmen Consoli. 
APPENDIX.

POETRY AND LYRICS - CASE STUDIES

Reading poetry, or even listening to it, demands an intentional process, a precise will and awareness ${ }^{15}$.

Popular songs instead persist in the collective memory, as well as in the individual memory, to which they often work as a reminder of a particular moment or emotion.

Poems and song lyrics have many points in common: they both rely on musicality, rhythm, pauses, rhymes, figures of speech: these means of expression are so similar that, in ancient times, poets used to read, or sing, their texts out loud while playing an instrument.

The inner musicality of poetry is also testified by its genres: sonnets, ballads, song, all terms referring to music.

But how similar and how different is poetry from lyrics meant for music?

Here are some statements of famous Italian poets about poetry and songwriting:

Pier Paolo Pasolini: "songs are not poetry, but they have an objective poetic value."

Edoardo Sanguineti: "It's confusing to consider songs at the same league as poetry: this confusion comes from a vanguard idea of contamination of genres."

Valerio Magrelli: "Words are energy, but they produce something different according to the way and means they are expressed through."

15 Alfio Squillaci points this out in La canzone italiana tra poesia e quotidianità, cit. 
Maurizio Cucchi: "Songs and poetry are different. In a song, words are somehow servants to music. But a fragment of song can be truly poetic, just like a verse."

Mario Desiati: "There is an undeniable point of contact between song and poetry, and this is rhythm."

This is instead what De Gregori and Guccini, two of the most outstanding living Italian songwriters, say on the matter:

Francesco De Gregori: "Songs will never be poetry, because in songs words are not independent, they are meant for the music, they are built around a melody. But they are literature, just like a theatrical text."

Francesco Guccini: "I wrote songs, not poems. My lyrics are meant to be sung: music and lyrics cannot be divided without losing something of their mutual essence. Poetry should be read out loud, and its musicality lies in the words themselves."

We can finally share De Gregori's idea that poetry and lyrics for music are very similar but in fact different genres and, most importantly, they both can be considered as literary forms of expression.

We will try now a brief comparison between two songwriter's songs inspired by the same topic (case study I) and between a poem and a song inspired by the same topic (case study II). 


\author{
CASE STUDY I \\ TWO SONGS INSPIRED BY THE SAME MYTH.
}

A COMPARISON

\title{
Euridice by Roberto Vecchioni (1993, Blumùn, EMI)
}

\section{Orfeo by Carmen Consoli (2000, Stato di necessità, Polydor Records)}

Euridice is the beautiful young Nymph spouse to Orpheus, unsurpassable lyre player. In order to escape from a shepherd in love with her, Euridice runs in the forest, where she is bitten by a snake and dies. Come down to Hell in order to find his lost love, Orpheus plays a sublime music, so that the gods of Hell, moved, accept to bring Euridice back to life, but on condition that Orpheus never turns his head back while he takes the spouse along the way out of Hell.

Orpheus is close to the gates of daylight, out of Hell, when, unable to resist to the desire of looking at the face of Euridice, he turns back, and in doing so, he loses her forever.

In Vecchioni's song, "the narrating voice" is Orpheus.

In the first part he addresses to the King of the Hell, Pluto, cursing him for the loss of his love Euridice, opposing to the tearing pain his own ars poetica, his wonderful chant.

Orpheus is conscious of his talent: his chant is no prayer, but a nearly arrogant affirmation of his own exceptional talent. He is sure to succeed in moving even the terrible masters of Darkness, the sovereigns of Hell, just by singing and playing about love, war, and the cruel destiny of men. But Orpheus's attitude changes soon: to the desperate and fierce rage of the opening lines, a second part follows, in which Orpheus surrenders to the thought of losing Euridice, leaving her in the reign of the Dead. 
Vecchioni inserts explicit references to the Greek tradition: one reference is given by the black sails (vele nere), those that were displayed on the ships returning from a war, when some soldiers had died (Orpheus himself was part of the famous shipment of the "Argonauts").

There is also a particularly elegant "stylistic" reference, given by the alternation of two voices, the one of Orpheus, and another one, similar to the Chorus that in ancient Greek tragedies had the function of expressing to the public the true feelings of the character playing on the scene.

According to the interpretation that Vecchioni gives of the myth, Orpheus turns his head deliberately, choosing therefore to lose Euridice forever: he refuses to abandon himself to the memory, in order to live his life fully again.

In Carmen Consoli's song, Euridice is the "narrating voice": the author chooses to sing about the moment when she is walking with Orpheus on the path that from Hell brings to the world again.

Consoli's Euridice has quite a severe attitude towards Orpheus ("Orfeo malato» - «ill Orpheus» - she calls him): she is suspicious and hard on him ("sei venuto a convincermi, o biasimarmi per ciò che non ho ancora imparato?» - "have you come to convince me, or blame me for what I have not learned yet?").

Consoli gives a very contemporary perspective to the ancient myth, and describes Orpheus and Euridice almost as a quarrelling modern young couple.

Euridice's attitude is harsh, but she is so willing to come back to life that she hangs with all her strength to her saviour Orpheus. Consoli chooses to fix a moment of hope for Euridice, who has just found his lost love and does not know yet that she will be forced to lose him again. 
Perhaps the hardness of Euridice is an anticipation of the cruel disillusion the girl is soon to be facing, because of Orpheus, "distratto da voci che inducono in tentazione» - "distracted by tempting voices".

Vecchioni and Consoli's songs both tell the same story from two different points of view.

It is peculiar that the narrating voices are inverted with respect to the title (In "Orfeo", Euridice speakes her voice, in "Euridice", Orpheus speaks his voice...)

Vecchioni sings about an Orpheus who decides, with a coup de theâtre, of losing Euridice to immerse himself into the joys of life again. Consoli sings the momentary excitement of Euridice, her hope to come back to life thanks to her darling Orpheus.

In both songs, despite the differences, what prevails is a feeling of melancholy and disillusion, due to the anticipation that Euridice will be abandoned by Orpheus, almost a premonition of a sad event, even though both songs refer one to the future happy life of Orpheus, the other to the happiness felt by Euridice in coming out from Hell.

Vecchioni's lyrics are very effective in recreating the settings and atmospheres of Ancient Greece, they are more complex and articulate than Consoli's, full of literary references, and he also uses a refined syntactic construction and incisive language. That is why Vecchioni's lyrics are a step closer to poetry than Consoli's. 


\title{
CASE STUDY I I
}

\section{A SONGWRITER'S SONG AND A POEM INSPIRED BY THE SAME TOPIC. A COMPARISON}

\section{Francesco De Gregori A Pà (1985, Scacchi e Tarocchi, RCA Records)}

\author{
Attilio Bertolucci, A Pasolini (in risposta), in Viaggio d'inverno \\ (1971, Garzanti, Milano)
}

Francesco De Gregori, never met Pier Paolo Pasolini, while Attilio Bertolucci (1911 - 2000), was a very close friend to him, the Italian perhaps most influential and controversial intellectual, murdered in 1975 in Ostia, near Rome, officially by a young man he was trying to seduce. Decades later, the truth on this murder has not been unveiled yet.

Nowadays, though, is becoming more and more popular the hypothesis that Pasolini was victim of a political murder committed by right-wing extremist criminals: his last film Salò disappeared in mysterious circumstances, and it seems that Pasolini was in Ostia that night to meet the people who stole the copies of his film and to make arrangements to have them back.

Both De Gregori's lyrics and Bertolucci's poem focus on the idea of brevity of life: this was true especially for Pasolini, who died too soon, brutally killed by criminal hands.

They also both focus on Pasolini's purity and honesty of thought (symbolized by lilies in the field, or night butterflies).

These are both very agile compositions, brief and concentrated, quite "easy" in language, like a thought dedicated to a friend who is doomed to be gone too soon. They are also both directly addressed to Pasolini as a you $(t u)$, in a very personal and intimate way. 
De Gregori's lyrics, very close to poetry indeed, are perhaps more focused on the joy of living, they remind of the vivacity of the poor young boys depicted by Pasolini in his films and novels.

He also impersonates one of those boys, those ragazzi di vita, by pretending to be present that night in Ostia, near the seaside, where Pasolini was killed.

Bertolucci's poem has instead a sadder, disillusioned attitude towards death: "(eppure vita era anche il giorno che muore)" [(but life was also the day that dies)]. Life is made of death, and the mature poet is well aware of that.

A Roberto

(Notes from the seminar held on 10.03.08 at University of Coimbra, Faculty of Letters - Department of Anglo-American Studies - Poets in Residence Programme 2008.)

\section{Bibliography}

L. Baldacci, La musica in italiano. Libretti d'opera dell'Ottocento, Rizzoli, Milano 1996

G. Baldazzi, La canzone italiana del Novecento, Newton Compton, Roma 1989

G. Borgna, La grande evasione. Storia del Festival di Sanremo: 30 anni di costume italiano, Savelli, Roma 1980

G. Borgna, Storia della canzone italiana, Mondadori, Milano 1992

G. Castaldo, a cura di, Dizionario della canzone italiana, Armando Curcio Editore, Roma 1990

P. Jachia, La canzone d'autore italiana 1958-1997, Feltrinelli, Milano 1998

F. Liperi, Storia della canzone italiana, Rai-Eri, Roma 1999

V. Mollica e S. Sacchi, Noi, i cantautori. Club Tenco e dintorni, Lato Side, Roma 1982

P. Scialò, La canzone napoletana dalle origini ai giorni nostri, Newton, Roma 1996 
Alfio Squillaci in La canzone italiana tra poesia e quotidianità. Appunti sparsi per una lezione da tenersi all'Istituto della Comunicazione di Milano, maggio 2003, http://www.lafrusta.net/fili_canzone_italiana.html

Roberto Vecchioni, Lezioni sulla canzone d'autore italiana, formerly published on http://www.vecchioni.it

Roberto Vecchioni, Canzone d'autore, Treccani Encyclopedia (1998), http://www. vecchioni.org/editoria/voce-canzone-dautore-scritta-per-lenciclopedia-treccani/ 